\title{
HUBUNGAN KADAR CA-125 PRAOPERATIF TERHADAP PROGNOSIS SURVIVAL PENDERITA KANKER OVARIUM EPITELIAL DI RSUP DR. SARDJITO
}

\author{
Herlina Prajatmoํㅗㄴ, Rukmono Siswishanto², Shinta Prawitasari³
}

\begin{abstract}
Background: CA-125 level increases in $50 \%$ of patients with stage I, $90 \%$ of patients with stage II, $92 \%$ of patients with stage III and $94 \%$ of patients with stage IV ovarian cancer. CA-125 level were not a diagnostic tool to detect ovarian cancer, however it was useful to monitor the progressive of disease and as a prognostic marker.

Objectives: The aim of this study is to prove whether CA-125 level before surgery in ovarian cancer patients at Dr. Sardjito Hospital as well as a factor that correlates to the survival prognosis of those patients.

Method: This research used cohort retrospective study at Dr. Sardjito Hospital Yogyakarta.

Result and Discussion: As much as 71 ovarian cancer patients which had been included in this research with inclusion and exclusion criteria. Subjects were divided into two groups. One group was for patients with low CA-125 level $(\leq 35 \mathrm{U} / \mathrm{ml})$ as much as 18 subjects and another group was for patients with high CA-125 level (>35 U/ml) as much as 53 subjects. The result of a bivariate analysis with an independent survival analysis (Cox's Regression) was the stage of disease ( $p=0.005, \mathrm{HR} 4.827, \mathrm{Cl} 95 \% 1.623-14.355$ ) and residual tumour ( $p=0.029, \mathrm{HR} 2.605, \mathrm{Cl} 95 \% 1.101-6.161$ ) were a survival prognosis factor. Multivariate analysis with a survival analysis (Cox's Regression) shows CA-125 level ( $p=0.031, \mathrm{HR} 4.131, \mathrm{Cl} 95 \% 1.143-$ $14.933)$ and menarche $(p=0.003, \mathrm{HR} 4.989, \mathrm{Cl} 95 \% 1.736-14.342)$ were significantly related with survival prognosis in EOC (Epithelial Ovarian Cancer) patients at Dr. Sardjito Hospital.

Conclusion: CA-125 level affects the survival rate of epithelial ovarian cancer patients in Dr. Sardjito Hospital. Besides the level of CA-125, there are other factors that affect the survival rate of epithelial ovarian cancer patients which is the stage of cancer, residual operation and age of menarche.
\end{abstract}

Keywords: CA-125 level, EOC, prognosis, survival.

\begin{abstract}
ABSTRAK
Latar Belakang: Kadar CA-125 meningkat pada 50\% pasien stadium I penyakit, $90 \%$ stadium II, $92 \%$ stadium III, 94\% stadium IV penyakit kanker ovarium. Kadar CA-125 bukan penanda diagnostik untuk mendeteksi kanker ovarium, tetapi merupakan penanda tumor yang bermanfaat untuk memonitor perjalanan penyakit dan sebagai penanda prognostik.
\end{abstract}

Tujuan: Untuk mengetahui apakah kadar CA-125 sebelum operasi penderita kanker ovarium di RSUP Dr. Sardjito juga merupakan faktor yang berhubungan dengan prognosis survival penderitanya.

Metode: Penelitian ini menggunakan rancangan kohort retrospektif.

Tempat penelitian: RSUP Dr. Sardjito Yogyakarta.

Hasil dan Pembahasan: Sebanyak 71 penderita kanker ovarium yang disertakan dalam penelitian ini sesuai dengan kriteria inklusi dan eksklusi. Subyek dibagi menjadi 2 kelompok yaitu kelompok kadar CA-125 rendah ( $\leq 35 \mathrm{U} / \mathrm{ml}$ ) sebanyak 18 subyek dan kelompok kadar CA-125 tinggi (>35 U/ml) sebanyak 53 subyek. Dari

1,2,3 Departemen Obstetri dan Ginekologi FKKMK Universitas Gadjah Mada Yogyakarta 
analisis bivariat dengan survival analisis (Cox's Regression) secara independen didapatkan stadium penyakit ( $p=0,005$; HR 4,827; IK 95\% 1,623-14,355) dan residu tumor ( $p=0,029$; HR 2,605; IK 95\% 1,101-6,161) merupakan faktor prognosis survival dari penderita EOC (Epithelial Ovarian Cancer). Dari analisis multivariat dengan survival analisis (Cox's Regression) didapatkan faktor yang berpengaruh terhadap survival penderita EOC di RSUP Dr. Sardjito baik secara statistik dan secara klinis adalah kadar CA-125 dengan ( $p=0,031 ; \mathrm{HR}$ 4,131; IK 95\% 1,143-14,933), dan menarche dengan ( $p=0,003$; HR 4,989; IK 95\% 1,736-14,342).

Kesimpulan: Kadar CA-125 berpengaruh terhadap survival penderita kanker ovarium epitelial di RSUP Dr. Sardjito. Selain kadar CA-125, terdapat faktor-faktor lain yang berpengaruh terhadap survival penderita kanker ovarium epitelial yaitu stadium kanker ovarium, residu operasi, dan umur menarche.

Kata kunci: Kadar CA-125, EOC, prognosis, survival.

\section{PENDAHULUAN}

Kanker ovarium adalah tumor ganas ginekologi yang tidak mempunyai gejala klinis yang patognomonis dan akan berkembang secara diam-diam di dalam tubuh wanita hingga pada suatu waktu menimbulkan keluhan. Keluhan dapat berupa gangguan akibat desakan massa tumor pada organ-organ pelvis, atau akibat penyebaran kanker ke daerah rongga perut, hepar, usus, ginjal, omentum dan diafragma. Perkembangan secara diamdiam ini menyebabkan angka harapan hidup 5 tahun penderita kanker ovarium cukup rendah dibandingkan kanker ginekologik lainnya. ${ }^{1}$

Beberapa faktor yang mempengaruhi angka harapan hidup 5 tahun penderita kanker ovarium adalah stadium penyakit, jenis histopatologi, terapi yang diberikan, residu tumor dan usia. Angka harapan hidup 5 tahun untuk kanker stadium I dan II adalah 95\% dan untuk stadium III dan IV adalah 31\%. Secara keseluruhan, angka harapan hidup 5 tahun penderita kanker ovarium adalah $53 \% .^{2}$ Angka harapan hidup ini berbeda jika dilihat menurut umur penderita. Penderita dengan usia kurang dari 50 tahun adalah sekitar $40 \%$ (secara keseluruhan), sedangkan untuk penderita dengan usia lebih dari 50 tahun adalah 15\%. The National Cancer Institutes, menyebutkan bahwa angka harapan hidup 5 tahun penderita kanker ovarium juga tergantung dari derajat diferensiasi sel tumor serta jenis histopatologisny a. ${ }^{3}$ Penatalaksanaan pertama dari kanker ovarium adalah pembedahan. Pembedahan dianggap optimal bila prosedur operasi dilakukan dengan residu tumor kurang dari $1 \mathrm{~cm}$. Bila prosedur operasi tidak seluruhnya dilakukan maka operasi belum lengkap (uncompleted staging). Pada kanker ovarium stadium I C atau lebih diberikan kemoterapi ajuvan dalam bentuk kombinasi dengan maksud agar respon terapi lebih baik dan resistensi obat kecil tetapi efek samping lebih ringan. Kemoterapi kombinasi sebaiknya tidak bekerja pada siklus sel yang sama dan tidak mempunyai efek samping pada organ yang sama pula. Terapi ajuvan radiasi hanya diberikan pada kanker ovarium jenis disgerminoma dan pada wanita yang sudah tidak menginginkan anak. Pada penderita yang masih menginginkan anak maka terapi ajuvan yang diberikan adalah kemoterapi. Beberapa usaha lain dalam pengelolaan kanker ovarium telah dilakukan, tetapi hingga dekade terakhir ini masih belum menunjukkan hasil yang memuaskan. Salah satu diantara penelitian yang telah dilakukan adalah dengan menggunakan CA125 sebagai prediktor prognosis kanker ovarium. ${ }^{4}$ Perubahan kadar CA-125 dapat digunakan sebagai indikator yang dapat dipercaya untuk menilai respon atau progresi kanker ovarium 
berdasar berbagai kriteria, akan tetapi CA-125 belum jelas diketahui perannya untuk diagnosis dan prognosis. Peran CA-125 sebagai metode skrining dan follow up rutin masih merupakan topik yang terus diteliti. ${ }^{5}$

CA-125 adalah protein yang didapat dalam darah pada berbagai keadaan termasuk pada kanker ovarium. Tes ini tidak cukup sensitif mendiagnosis stadium awal penyakit. Walaupun lebih dari $85 \%$ penderita kanker ovarium stadium lanjut terjadi kenaikan kadar CA-125 ( $>35 \mathrm{U} / \mathrm{ml}$ ), ternyata hanya $50 \%$ yang mengalami kenaikan pada stadium awal penyakit. Selain itu peningkatan kadar CA-125 lebih dari $35 \mathrm{U} /$ $\mathrm{ml}$ didapati pada $6 \%$ populasi tanpa menderita kanker ovarium. ${ }^{6}$ Meskipun pemeriksaan CA125 tidak spesifik untuk mendiagnosis kanker ovarium namun potensial digunakan untuk menilai, memonitor, dan mengevaluasi respon terapi pada kanker ovarium. Penurunan kadar CA-125 secara serial menunjukkan adanya respon positif terhadap terapi dan sebaliknya. ${ }^{7}$ Kanker ovarium epitelial tipe serosa mengekpresikan CA-125 lebih tinggi secara bermakna dibanding tipe kanker ovarium epitelial lainnya. Angka harapan hidup 5 tahun yang lebih pendek secara bermakna didapatkan pada penderita kanker ovarium stadium III dan IV tanpa ekspresi CA-125 dibandingkan dengan yang ada ekspresi CA-125. .

Berdasarkan uraian latar belakang di atas, peneliti tertarik untuk melihat hubungan kadar CA-125 praoperatif dengan prognosis survival kanker ovarium.

\section{METODE}

Penelitian dilakukan dengan menggunakan rancangan penelitian kohort retrospektif, untuk memperoleh cara dalam memprediksi survival penderita kanker ovarium di RSUP Dr. Sardjito dan mengetahui faktor-faktor lain yang mempengaruhi prognosis survival penderita kanker ovarium di RSUP Dr. Sardjito. Penelitian dilakukan dengan mengambil data dari rekam medik sejak tahun 2007 sampai dengan 2011, kemudian follow up penderita diikuti sampai akhir tahun 2013. Subyek penelitian sebanyak 71 pasien dengan kriteria inklusi: penderita kanker ovarium yang sebelum operasi diperiksa kadar CA-125 darah, dilakukan operasi di RSUP Dr. Sardjito, mendapat kemoterapi di RSUP Dr. Sardjito, dan jenis kanker ovarium yang diperiksa adalah jenis tumor epitelial. Kriteria eksklusi adalah: penderita kanker ovarium tetapi didapat keganasan yang lain, tidak mendapat terapi lanjutan kemoterapi, dan alamat yang tidak lengkap atau tidak terjangkau komunikasi.

Variabel bebas penelitian adalah kadar CA125 serum darah praoperatif. Variabel tergantung adalah kemampuan hidup (survival) penderita. Adapun variabel luar meliputi umur penderita, jumlah paritas, Body Mass Index (BMI), stadium kanker ovarium, jenis histopatologi, derajat diferensiasi, residu operasi, status menopause, menarche, dan jumlah kemoterapi.

Analisis univariat, bivariat dan multivariat digunakan dalam penelitian ini. Uji chi-square digunakan untuk mengetahui hubungan CA-125 dengan variabel luar. Log rank test digunakan untuk mengetahui hubungan CA-125 dengan survival penderita. Analisis bivariat dan multivariat dengan survival analisis (Cox's regression) digunakan untuk mengetahui hubungan semua variabel terhadap variabel tergantung (survival).

\section{HASIL DAN PEMBAHASAN}

Dalam penelitian ini didapatkan subyek penelitian sebanyak 71 subyek yang dibagi 2 kelompok yaitu kelompok kadar CA-125 tinggi sebanyak 53 subyek dan kelompok kadar CA125 rendah sebanyak 18 subyek. Kelompok umur penderita kanker ovarium epitelial (EOC) di RSUP Dr. Sardjito pada kelompok umur $>40$ tahun sebanyak $71,8 \%$, hal ini sesuai dengan epidemiologi kanker ovarium. Proporsi paritas kelompok nulipara dengan multipara hampir 
sama yaitu berturut-turut $49,3 \%$ dan $50,7 \%$. Pada penelitian ini didapatkan lebih banyak pasien yang belum menopause yaitu sebanyak $50,7 \%$. Untuk yang kelompok menarche lebih banyak didapatkan pada kelompok < 15 tahun yaitu sebanyak 48 orang $(67,6 \%)$. Stadium penderita EOC didapatkan $56,3 \%$ dalam keadaan stadium lanjut (stadium III dan IV), sedangkan penderita dalam stadium awal (stadium I dan II) didapatkan sebanyak $43,7 \%$. Jenis histopatologi yang paling banyak didapat pada penelitian ini adalah jenis serosum atau musinosum sebanyak $76,1 \%$, dibandingkan dengan jenis endometrioid atau clear cell ca yaitu sebanyak $23,9 \%$. Residu operasi yang optimal ditemukan pada 41 pasien $(57,7 \%)$ dan yang tidak optimal sebanyak 30 pasien (42,3\%).

Tabel 1. Analisis Bivariat dengan Uji Chi-Square hubungan antara variabel bebas (kadar CA-125) dengan variabel luar

\begin{tabular}{|c|c|c|c|c|c|c|c|}
\hline \multirow{3}{*}{ Variabel } & \multicolumn{4}{|c|}{ Kadar CA-125 } & \multirow{3}{*}{ OR } & \multirow{3}{*}{$95 \% \mathrm{Cl}$} & \multirow{3}{*}{$p$} \\
\hline & \multicolumn{2}{|c|}{$\leq 35$} & \multicolumn{2}{|c|}{$>35$} & & & \\
\hline & $n$ & $\%$ & $\mathrm{n}$ & $\%$ & & & \\
\hline \multicolumn{8}{|l|}{ Umur penderita: } \\
\hline$\cdot \leq 40$ tahun & 6 & 8,5 & 14 & 19,7 & 1,393 & $0,439-4,419$ & 0,573 \\
\hline$\cdot>40$ tahun & 12 & 6,9 & 39 & 4,9 & & & \\
\hline \multicolumn{8}{|l|}{ Umur menarche: } \\
\hline$\bullet<15$ tahun & 11 & 15,5 & 37 & 52,1 & 0,680 & $0,223-2,071$ & 0,496 \\
\hline$\cdot \geq 15$ tahun & 7 & 9,9 & 16 & 22,5 & & & \\
\hline \multicolumn{8}{|l|}{ Paritas: } \\
\hline$\bullet<2$ & 7 & 9,9 & 28 & 39,4 & 0,568 & 0,191-1,691 & 0,307 \\
\hline$\cdot \geq 2$ & 11 & 15,5 & 25 & 35,2 & & & \\
\hline \multicolumn{8}{|l|}{ BMI: } \\
\hline$\bullet<\operatorname{normal}\left(25 \mathrm{~kg} / \mathrm{m}^{2}\right)$ & 14 & 19,7 & 39 & 54,9 & 1,256 & $0,354-4,465$ & 0,724 \\
\hline$\cdot \geq \operatorname{normal}\left(25 \mathrm{~kg} / \mathrm{m}^{2}\right)$ & 4 & 5,6 & 14 & 19,7 & & & \\
\hline \multicolumn{8}{|l|}{ Stadium penyakit: } \\
\hline - Awal (I atau II) & 8 & 11,3 & 23 & 32,4 & 1,043 & $0,356-3,063$ & 0,938 \\
\hline - Lanjut (III atau IV) & 10 & 14,1 & 30 & 42,3 & & & \\
\hline \multicolumn{8}{|l|}{ Jenis Histopatologi: } \\
\hline - Serosum atau Musinosum & 13 & 18,3 & 41 & 57,7 & 0,761 & $0,226-2,566$ & 0,659 \\
\hline - Endometrioid atau Clear Cell Ca & 5 & 7,0 & 12 & 16,9 & & & \\
\hline \multicolumn{8}{|l|}{ Derajat diferensiasi: } \\
\hline - Baik & 9 & 12,7 & 27 & 38,0 & 0,963 & $0,330-2,806$ & 0,945 \\
\hline - Sedang atau buruk & 9 & 12,7 & 26 & 6,6 & & & \\
\hline \multicolumn{8}{|l|}{ Residu operasi: } \\
\hline - Optimal & 9 & 12,7 & 32 & 45,1 & 0,656 & $0,224-1,924$ & 0,441 \\
\hline - Tidak optimal & 9 & 12,7 & 21 & 29,6 & & & \\
\hline \multicolumn{8}{|l|}{ Status menopause: } \\
\hline - Belum menopause & 13 & 18,3 & 23 & 32,4 & 3,391 & $1,057-10,880$ & $0,035^{*}$ \\
\hline - Menopause & 5 & 7,0 & 30 & 42,3 & & & \\
\hline \multicolumn{8}{|l|}{ Jumlah kemoterapi: } \\
\hline • $0-2$ & 3 & 4,2 & 12 & 16,9 & 0,683 & $0,169-2,762$ & 0,592 \\
\hline$\cdot \geq 3$ & 15 & 21,1 & 41 & 57,7 & & & \\
\hline
\end{tabular}

Keterangan: *bermakna $(p<0,05)$ 
Dari hasil bivariat (tabel 1) variabel bebas dengan variabel terikat, didapatkan bahwa kelompok umur, kelompok menarche, kelompok paritas, kelompok status gizi (BMI), kelompok stadium penyakit, kelompok jenis histopatologi, kelompok derajat diferensiasi, kelompok residu operasi, dan jumlah kemoterapi secara statistik dan secara klinis tidak ada hubungan yang bermakna dengan kelompok kadar CA125 dimana $p>0,05$ maupun $O R<2$ dan $>0,5$. Kelompok menopause terdapat hubungan secara statistik maupun secara klinis bermakna dengan kadar CA-125 dimana $\mathrm{p}<0,05$ dan $\mathrm{OR}>2$.

Tabel 2. Analisis bivariat dengan Log Rank Test untuk hubungan variabel bebas (CA-125) dengan variabel tergantung (survival penderita) pada penderita kanker ovarium epitelial di RSUP Dr. Sardjito

\begin{tabular}{|c|c|c|c|c|c|c|}
\hline \multirow[t]{2}{*}{ Variabel } & \multicolumn{4}{|c|}{ Case procesing summary } & \multicolumn{2}{|c|}{ Log rank test } \\
\hline & Event & $\%$ & Censor & $\%$ & $x^{2}$ & $p$ \\
\hline \multicolumn{7}{|l|}{ Kadar CA 125} \\
\hline$\cdot \leq 35 \mathrm{U} / \mathrm{ml}$ & 4 & 22,2 & 14 & 77,8 & 1,315 & 0,252 \\
\hline$\cdot>35 \mathrm{U} / \mathrm{ml}$ & 18 & 34,0 & 35 & 66,0 & & \\
\hline
\end{tabular}

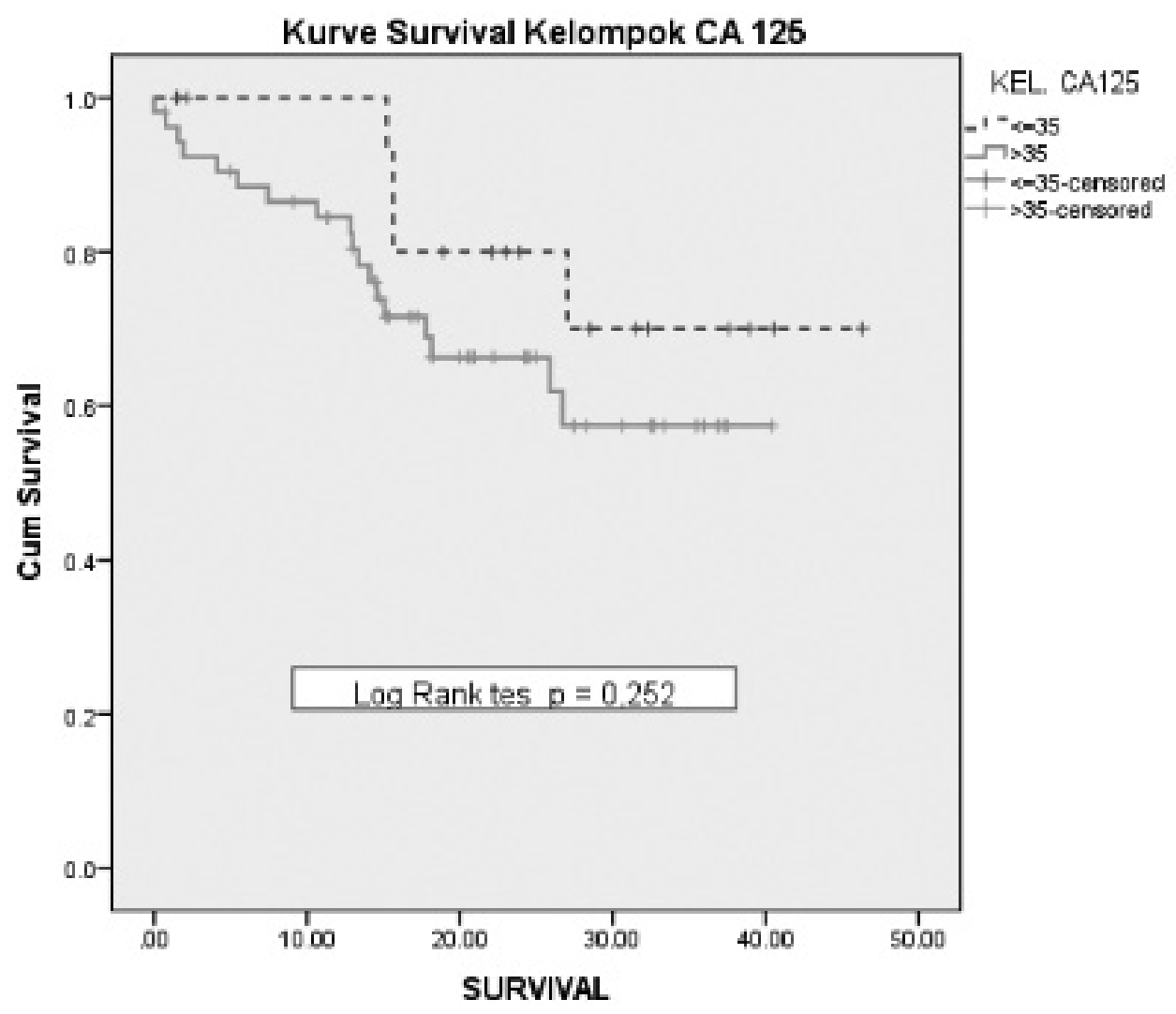

Gambar I. Kurva Kaplan-Meier survival penderita kanker ovarium epitelial berdasarkan kelompok kadar CA-125 ( $\leq 35 \mathrm{U} / \mathrm{ml}$ dan $>35 \mathrm{U} / \mathrm{ml})$ 
Survival penderita EOC di RSUP Dr. Sardjito berdasarkan kelompok kadar CA-125 (kelompok statistik tidak berbeda bermakna dimana dengan $\leq 35 \mathrm{U} / \mathrm{ml}$ dan kelompok >35 $\mathrm{U} / \mathrm{ml}$ ) secara Log Rank Test $p=0,252$ (Tabel 2 dan gambar 1).

Tabel 3. Analisis bivariat dan multivariat dengan survival analisis (Cox's regression)

\begin{tabular}{|c|c|c|c|c|}
\hline \multirow{2}{*}{ Variabel } & \multicolumn{2}{|c|}{ Analisis Bivariat } & \multicolumn{2}{|c|}{ Analsis Multivariat } \\
\hline & HR (95\% Cl) & $p$ & HR $(95 \% \mathrm{Cl})$ & $p$ \\
\hline \multicolumn{5}{|l|}{ CA 125} \\
\hline $\begin{array}{l}\cdot \leq 35 \mathrm{U} / \mathrm{ml} \\
\cdot>35 \mathrm{U} / \mathrm{ml} \\
\end{array}$ & $\begin{array}{c}\text { Ref. } 1,868 \\
(0,630-5,538) \\
\end{array}$ & 0,260 & $\begin{array}{c}\text { Ref. } 4,131 \\
(1,143-14,933) \\
\end{array}$ & $0,031^{*}$ \\
\hline \multicolumn{5}{|l|}{ Kelompok umur } \\
\hline $\begin{array}{l}\cdot \leq 40 \text { tahun } \\
\cdot>40 \text { tahun }\end{array}$ & $\begin{array}{c}\text { Ref. } 1,938 \\
(0,671-5,864) \\
\end{array}$ & 0,216 & $\begin{array}{c}\text { Ref. } 1,986 \\
(0,570-6,919)\end{array}$ & 0,281 \\
\hline \multicolumn{5}{|l|}{ Menarche } \\
\hline $\begin{array}{l}\cdot<15 \text { tahun } \\
\cdot \geq 15 \text { tahun }\end{array}$ & $\begin{array}{c}\text { Ref. } 2,643 \\
(1,142-6,117) \\
\end{array}$ & $0,023^{*}$ & $\begin{array}{c}\text { Ref. } 4,989 \\
(1,736-14,342) \\
\end{array}$ & $0,003^{*}$ \\
\hline \multicolumn{5}{|l|}{ Paritas } \\
\hline $\begin{array}{l}\cdot<2 \\
\cdot \geq 2 \\
\end{array}$ & $\begin{array}{c}\text { Ref. } 1,839 \\
(0,771-4,384)\end{array}$ & 0,170 & $\begin{array}{c}\text { Ref } 3,015 \\
(0,962-9,442) \\
\end{array}$ & 0,058 \\
\hline $\begin{array}{l}\text { Menopause } \\
\text { - Belum menopause } \\
\text { - Menopause } \\
\end{array}$ & $\begin{array}{c}\text { Ref } 0,870 \\
(0,377-2,009 \\
\end{array}$ & 0,744 & $\begin{array}{c}\text { Ref } 0,615 \\
(0,226-1,673) \\
\end{array}$ & 0,341 \\
\hline $\begin{array}{l}\text { BMI } \\
\quad \cdot<25 \mathrm{~kg} / \mathrm{m}^{2} \\
\cdot \geq 25 \mathrm{~kg} / \mathrm{m}^{2} \\
\end{array}$ & $\begin{array}{c}\text { Ref. } 0,656 \\
(0,222-1,939) \\
\end{array}$ & 0,446 & $\begin{array}{c}\text { Ref. } 0,579 \\
(0,176-1,904)\end{array}$ & 0,368 \\
\hline $\begin{array}{l}\text { Stadium penyakit } \\
\text { - Awal (I atau II) } \\
\text { - Lanjut (III atau IV) } \\
\end{array}$ & $\begin{array}{c}\text { Ref. } 4,827 \\
(1,623-14,355)\end{array}$ & $0,005^{*}$ & $\begin{array}{c}\text { Ref. } 4,567 \\
(0,910-22,929)\end{array}$ & 0,065 \\
\hline $\begin{array}{l}\text { Jenis Histopatologi } \\
\text { - Serosum atau musinosum } \\
\text { - Endometrioid atau Clear cell Ca }\end{array}$ & $\begin{array}{c}\text { Ref } 1,293(0,527- \\
3,175) \\
\end{array}$ & 0,575 & $\begin{array}{c}\text { Ref. } 0,600(0,183- \\
11,971) \\
\end{array}$ & 0,400 \\
\hline $\begin{array}{l}\text { Derajat diferensiasi } \\
\text { - Baik } \\
\text { - Sedang atau buruk } \\
\end{array}$ & $\begin{array}{c}\operatorname{Ref} 2,214 \\
(0,902-5,435) \\
\end{array}$ & 0,083 & $\begin{array}{c}\text { Ref. } 1,297 \\
(0,386-4,355) \\
\end{array}$ & 0,674 \\
\hline $\begin{array}{l}\text { Residu tumor } \\
\text { - Optimal } \\
\text { - Tidak optimal } \\
\end{array}$ & $\begin{array}{c}\operatorname{Ref} 2,605 \\
(1,101-6,161) \\
\end{array}$ & $0,029^{*}$ & $\begin{array}{c}\text { Ref. } 0,818 \\
(0,259-2,590) \\
\end{array}$ & 0,731 \\
\hline $\begin{array}{l}\text { Jumlah kemoterapi } \\
\qquad 0-2 \\
\cdot \geq 3\end{array}$ & $\begin{array}{c}\text { Ref } 1,011 \\
(0,340-3,002)\end{array}$ & 0,985 & $\begin{array}{c}\text { Ref. } 1,958 \\
(0,522-7,321)\end{array}$ & 0,319 \\
\hline
\end{tabular}

Keterangan: *bermakna $(p<0,05)$ 
Hasil analisis bivariat dengan Cox's Regression hubungan survival penderita EOC di RSUP Dr. Sardjito dengan kelompok-kelompok variabel luar didapat kelompok stadium penyakit, kelompok residu operasi, kelompok menarche berbeda bermakna dengan nilai $p$ berturutturut $p=0,005, p=0,029, p=0,023$. Kelompok variabel-variabel lain tidak berbeda bermakna dengan $p>0,05$. Hasil analisis multivariat (Cox's Regression) pada tabel 3 didapatkan faktor atau variabel kelompok yang berpengaruh terhadap survival penderita EOC di RSUP Dr. Sardjito baik secara statistik dan secara klinis adalah kadar CA125 dengan $p=0,031$ dan $H R=4,131$, menarche dengan $p=0,003$ dan $H R=4,989$. Faktor-faktor paritas dan stadium penyakit secara klinis berpengaruh bermakna dengan berturut-turut $H R=3,015(p=0,058)$ dan $H R 4,567(p=0,065)$.

Dari data penelitian ini didapatkan bahwa menarche, stadium penyakit, dan residu tumor secara independen merupakan faktor prognosis survival dari penderita EOC berturut-turut dengan $p=0,023, p=0,005, p=0,029$. Pada analisis multivariat (adjusted terhadap variabel lain) hanya status menarche yang bermakna sebagai faktor prognosis survival dengan $p=0,003$ (Tabel 6). Sejauh penelusuran literatur yang dilakukan tidak ada laporan yang menyebutkan bahwa menarche berhubungan dengan prognosis survival penderita EOC. Umur saat menarche biasanya berhubungan dengan risiko patogenesis terjadinya kanker ovarium.Tetapi di penelitian ini didapatkan menarche sebagai faktor prognosis survival, dimana usia menarche $\geq 15$ tahun risiko kematian meningkat 4,989 kali lebih tinggi dibanding penderita yang usia menarche $<15$ tahun. Pada penelitian ini didapatkan kadar CA125 secara independen bukan merupakan faktor prognosis survival, tetapi pada analisis multivariat (adjusted analisis terhadap variabel lain) kadar CA-125 merupakan faktor prognosis survival penderita kanker ovarium dengan $H R$ 4,131 dan $p=0,031$ (Tabel 6). Kadar CA-125 pada penelitian ini diklasifikasikan menjadi 2 grup dengan cut off point $35 \mathrm{U} / \mathrm{ml}$. Dengan demikian penderita EOC dengan kadar CA-125 >35 U/ml risiko kematian 4,131 kali lebih besar dibanding penderita EOC dengan kadar CA-125 $\leq 35 \mathrm{U} / \mathrm{ml}$.

Penelitian lain juga mendapatkan bahwa kadar CA-125 merupakan faktor prognosis survival untuk penderita EOC stadium I. ${ }^{99}$ Review dari 15 penelitian menunjukkan bahwa kadar CA125 meningkat pada $50 \%$ pasien dengan stadium I penyakit, $90 \%$ pada stadium II, $92 \%$ pada stadium III, dan $94 \%$ pada stadium IV penyakit. ${ }^{10}$ Dilaporkan juga bahwa terdapat korelasi positif antara peningkatan kadar serum CA-125 dan tingkat ekspresi CA-125 pada jaringan kanker ovarium epithelial. Pada kanker ovarium epithelial tipe serosum ekspresi CA-125 lebih positif bermakna dibanding tipe-tipe yang lain. CA-125 mungkin juga berperan dalam mengurangi sensitivitas selsel kanker terhadap terapi obat. Over ekspresi CA-125 telah ditunjukkan melindungi sel-sel dari efek obat-obat genotoxic seperti Cisplatin ${ }^{11}$. Akan tetapi peneliti lain mendapatkan bahwa survival penderita kanker ovarium stadium III dan IV dengan tanpa ekspresi CA-125 dalam jaringan tumornya survivalnya lebih pendek bermakna dibanding dengan pasien kanker ovarium stadium III dan IV dengan ekspresi CA-125 didalam jaringan tumornya. ${ }^{8}$ Stadium klinis selalu disebutkan sebagai faktor prognosis kanker yang paling penting. Kemampuan hidup 5 tahun relatif penderita kanker ovarium semua stadium adalah 53\%, untuk stadium III dan IV adalah 31\%, dan stadium I dan II adalah $95 \%$. $^{2}$ Pada penelitian ini didapatkan bahwa stadium klinis secara independen merupakan faktor prognosis survival yang bermakna pada penderita EOC dengan $H R$ 4,827 dan $p=0,005$, sedangkan pada adjusted analisis (multivariat analisis) stadium penyakit secara statistik tidak bermakna dengan $p=0,065$, akan tetapi secara klinis bermakna dengan 
$H R$ 4,567, hal ini disebabkan karena kekuatan penelitian yang kurang (Tabel 6).

Residu tumor dalam penelitian ini secara independen merupakan faktor prognosis survival penderita EOC dengan $H R$ 2,605 dan $p=0,029$, akan tetapi pada adjusted analisis bukan merupakan faktor prognosis survival dengan $H R$ 0,818 dan $p=0,731$. Hal ini mungkin masih bisa terjadi karena $H R$ masih berada dalam kisaran Cl (Tabel 6). Para peneliti menyebutkan bahwa residu tumor merupakan faktor prognosis survival pada pasien EOC stadium IV ${ }^{12}$. Menurut Elstrand et al., melaporkan bahwa diantara pasien-pasien EOC stadium IV yang dilakukan 1 kali operasi residual tumor merupakan faktor prognosis yang penting untuk survival secara keseluruhan (overall survival). ${ }^{13}$

Pada penelitian ini EOC sebagian besar terjadi pada usia $>40$ tahun sebanyak $71,8 \%$ dan $28,2 \%$ pada usia $\leq 40$ tahun, penelitian lain melaporkan bahwa kanker ovarium 3-17\% terjadi pada usia $<40$ tahun. ${ }^{14}$ Implikasi umur pada kanker ovarium umumnya tidak pasti. Walaupun kebanyakan studi menunjukkan bahwa wanita usia muda dengan kanker ovarium mempunyai outcome yang lebih baik dibandingkan wanita usia lebih tua karena mereka mempunyai stadium yang lebih rendah dan derajat diferensiasi tumor yang baik. Faktor paritas pada penelitian ini didapatkan bahwa penderita EOC dengan paritas lebih dari satu anak secara independen mempunyai risiko survival yang lebih rendah dibanding penderita dengan satu anak atau tanpa anak dengan HR 1,839 dan $p=0,170$, dan pada adjusted analisis didapatkan $H R \quad 3,015$ dengan $p=0,058$. Walaupun secara statistik tidak bermakna tetapi secara klinis bermakna, hal ini karena kekuatan penelitian yang kurang. Sejauh penelusuran literatur, peneliti tidak mendapatkan pengaruh paritas terhadap survival penderita EOC.
Pada penelitian ini jumlah kemoterapi tidak berpengaruh terhadap prognosis survival baik secara independen maupun adjusted analisis dimana $p$ berturut-turut $p=0,985$ dan $p=0,319$. Ini mungkin berkaitan dengan kadar CA-125 yang tetap persisten meningkat setelah kemoterapi sehingga prognosis penderita buruk. ${ }^{15}$ Faktorfaktor lain yang diteliti pada penelitian ini, seperti status menopause, BMI (status gizi), tipe histopatologi, dan derajat diferensiasi tidak berpengaruh terhadap survival penderita EOC.

\section{KESIMPULAN DAN SARAN}

Dari penelitian ini disimpulkan bahwa kadar CA-125 yang tinggi berhubungan dengan survival yang rendah pada penderita kanker ovarium epitelial di RSUP Dr. Sardjito. Selain kadar CA-125, terdapat faktor-faktor lain yang berpengaruh terhadap survival penderita kanker ovarium epitelial yaitu stadium kanker ovarium, residu operasi, dan menarche.

Pemeriksaan kadar CA-125 perlu dilakukan terhadap penderita tumor ovarium karena kadar CA-125 mempunyai nilai untuk memprediksi prognosis (survival) penderita. Disarankan dilakukan penelitian dengan sampel yang lebih banyak untuk dapat membuktikan faktor-faktor lain yang berpengaruh terhadap prognosis survival penderita kanker ovarium.

\section{DAFTAR PUSTAKA}

1. Berek JS, Fu YS, Hacker NF. 2002. Ovarian Cancer in Novak's Gynecology $13^{\text {th }} \mathrm{Ed}$, Williams \& Wilkins, Pensylvania; 1245-1320.

2. Landis SH, Murray T, Bolden S, Wingo P. 1998. Cancer statistics. CA Cancer J Clin. 48: 6-30.

3. Sloan J, Schwartz A, Qureshi F, Jacques S, Malone J, Munkarah A. 2003. Ovarian Cancer: Change in patterns at diagnosis and relative survival over the last three decades, Am J Obstet Gynecol; 189: 1120-7.

4. Tingulstad S, Skjeldestad FE, Halvorsen TB, Hagen B. 2003. Survival and Prognostic Factor in Patients With Ovarian Cancer. ACOG; 101: 885-891. 
5. Meyer T, Rustin GJ. 2000. Role of tumour markers in monitoring epithelial ovarian cancer. Br J Cancer. 82(9):1535-8.

6. Urban, N. 2003. Specific keynote: Ovarian cancer risk assessment and the potential for early detection. Gynecol. Oncol., 88(Suppl. 1), S75-S79.

7. American Cancer Society. How many women get ovarian cancer? Cited. 2004. February 22, available at www.cancer.org/docroot/CRI/content/CRI.

8. Hogdall, EV, Christensen L, Kjaer SK, Blaakaer L, Kjaerbye-Thygesen A, Gayther S, Jacobs IJ, Hogdall CK. 2007. CA 125 expression pattern, prognosis and correlation with serum CA 125 in ovarian tumor patients from the Danish "Malova" ovarian cancer study. Gynecol oncol. 104(3):508-17.

9. Nagele F, Petru E, Medl M, Kainz C, Graf AH, Sevelda P. 1995. Preoperative CA 125: an independent prognostic factor in patients with stage I epithelial ovarian cancer. Obstet Gynecol. 86: 259-64.

10. Jacobs I, Bast RC. 1999. The CA125 tumourassociated antigen: a review of the literature. Hum Reprod. 4:1-12.
11. Boivin M, Lane D, Piche A, Rancourt C. 2009. CA125 (MUC 16) tumor antigen selectivity modulates the sensitivity of ovarian cancer cells to genotoxic drug-induced apoptosis. Gynecol Oncol. 115 (3): 407-13.

12. Munkarah AR, Hallum AV, Morris M, Burke TW, Levenback C, Atkinson EN. 1997. Prognostic significance of residual disease in patients with stage IV epithelial ovarian cancer. Gynecol Oncol. 64:13-17.

13. Elstrand MB, Sandstad B, Oksefjell H, Davidson B, Trope CG. 2012. Prognostic significance of residual tumor in patients with epithelial ovarian carcinoma stage IV i a 20 year perspective. ACTA Obstet Gynecol Scan, 91:308-17.

14. Rodriguez M, Nguyen HN, Averette HE, Steren AJ, Penalver MA, Harrison T, Sevin BU. 1994. National survey of ovarian carcinoma XII. Epithelial ovarian malignancies in women less than or equal to 25 years of age. Cancer. 73: 1245-50.

15. Gocze P, Vahrson H. 1993. Ovarian cancer antigen (CA-125) and ovarian cancer (clinical follow-up and prognostic studies). Orv Hetil Hungarian. 134 (17): 915-8. 